\title{
Work-Family Enrichment dan Work Engagement pada Karyawan yang Sudah Menikah
}

\author{
Diaz Fahmi Zakiy Susilo ${ }^{(1)}$, Sowanya Ardi Prahara ${ }^{(1)}$ \\ ${ }^{(1)}$ Program Studi Psikologi, Universitas Mercu Buana Yogyakarta, Yogyakarta, Indonesia
}

\begin{abstract}
The current research aims to examine the relationship between work-family enrichment and work engagement among married employees. The design of the current research was a correlational survey in which the data were analysed using the Pearson's product moment correlation. Among 39 married employees at Wisma Wisma Yogyakarta who were drawn on the basis of the purposive sampling, the result revealed as hypothesised that work-family enrichment was significantly and positively correlated with work engagement. We discuss this empirical finding in terms of theoretical and practical implications, as well as directions for future studies.
\end{abstract}

Keywords: work-family enrichment, work engagement

Penelitian ini bertujuan untuk menguji hubungan antara work-family enrichment dengan work engagement pada karyawan yang sudah menikah. Penelitian ini didesain sebagai survei korelasional dimana data dianalisis menggunakan Pearson's product moment correlation. Subjek penelitian adalah 39 karyawan yang sudah menikah, yang direkrut atas dasar purposive sampling. Hasil penelitian mendukung hipotesis yang ditetapkan dimana work-family enrichment berhubungan secara signifikan ke arah positif dengan work engagement. Temuan penelitian ini didiskusikan baik dari segi implikasi teoretis dan praktis, serta saran-saran untuk penelitian lanjutan.

Kata kunci: work engagement, work-family enrichment

MEDIAPSI, 2019, Vol. 5(2), 108-116, DOI: https://doi.org/10.21776/ub.mps.2019.005.02.5

Received: 2019-08-04. Revised: 2019-09-11. Accepted: 2019-11-05. Published online: 2019-12-05

Handling Editor: Sumi Lestari, Universitas Brawijaya, Malang, Indonesia

*Corresponding author: Diaz Fahmi Zakiy Susilo, Program Studi Psikologi, Universitas Mercu Buana Yogyakarta, Yogyakarta, Indonesia. E-mail: diazfahmi12@gmail.com

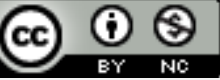

This work is licensed under a Creative Commons Attribution-NonCommercial 4.0 International License.

How to cite this article in accordance with the American Psychological Association (APA) $6^{\text {th }}$ guidelines:

Susilo, D. F. Z., \& Prahara, S. A. (2019). Work-family enrichment dan work-engagement pada karyawan yang sudah menikah. MEDIAPSI, 5(2), 108-116. DOI: https://doi.org/10.21776/ub.mps.2019.005.02.5

\section{Pendahuluan}

Dalam suatu organisasi, sumber daya manusia sebagai salah satu sumber daya yang ada memegang peranan penting dalam keberhasilan pencapaian tujuan organisasi (Caldwell, Truong, Linh, \& Tuan, 2011). Berhasil atau tidaknya pencapaian tujuan ini tergantung pada sejumlah faktor. Salah satu faktor tersebut adalah kemampuan sumber daya manusia itu sendiri dalam menjalankan tugas dan fungsinya. Hal ini disebabkan karena manusia selalu berperan aktif dan selalu dominan dalam setiap aktifitas organisasi karena manusia menjadi perencana, pelaku, sekaligus penentu terwujudnya tujuan organisasi (Samsuni, 2017). Sumber daya manusia menjadi sumber daya yang penting bagi organisasi untuk tetap kompetitif. Sumber daya manusia merupakan elemen utama dalam organisasi dibandingkan dengan elemen yang lain seperti modal, teknologi dan uang sebab manusia sendiri yang mengendalikan elemenelemen tersebut (Hariandja, dalam Wulandari, Nurtjahjanti, \& Putra, 2013). 
Karyawan berdasarkan status perkawinannya dapat dibedakan menjadi dua, yaitu karyawan yang belum menikah dan karyawan yang sudah menikah (berkeluarga). Fakta bahwa suami istri harus bersama-sama mencari nafkah (bekerja) untuk masa depan keluarganya sudah lazim terjadi dalam era globalisasi ini (Amelia, 2010). Fenomena ini juga terjadi di Wisma Bahasa Yogyakarta dengan jumlah karyawan yang sudah menikah mencapai 39 orang dari total 66 karyawan yang ada di tempat tersebut.

Dengan pengalaman lebih dari 36 tahun, Wisma Bahasa Yogyakarta telah menunjukkan kemampuannya dalam berkompetisi dan berhasil mempertahankan posisinya sebagai pemimpin pasar di antara lembaga pelatihan bahasa di Yogyakarta. Kunci kesuksesan ini adalah kemampuan Wisma Bahasa dalam memberikan layanan bahasa yang sangat konsisten dan berkualitas tinggi melalui komitmen untuk perbaikan yang berkelanjutan. Dari satu jenis layanan bahasa pada tahun-tahun awal, sekarang organisasi Wisma Bahasa Yogyakarta telah meningkatkan dan memperluas produknya dengan menyediakan layanan pendidikan dan pelatihan berkualitas tinggi bagi individu yang perlu meningkatkan keterampilan bahasa Indonesia atau bahasa Indonesia untuk tujuan pekerjaan, migrasi atau studi. Wisma Bahasa Yogyakarta menyediakan kursus tidak hanya bahasa, tetapi juga studi budaya, seperti lukisan batik, tarian tradisional, dan memasak. Program kursus Bahasa Indonesia terdiri dari kursus intensif dan khusus, yang akan dilakukan untuk kelas individu maupun kelompok.

Wisma Bahasa Yogyakarta memiliki visi untuk menjadi lembaga kursus Bahasa Indonesia untuk orang asing terbaik di dunia. Oleh karena itu karyawan Wisma Bahasa Yogyakarta dituntut untuk mampu menyediakan pelatihan bahasa Indonesia untuk orang asing di mana lulusannya memenuhi standar nasional dan internasional, yang mampu memberikan layanan berkualitas tinggi yang berfokus pada kepuasan pelanggan serta penyiapan armada kerja yang mampu menangani berbagai tantangan kekaryaan dengan standar kelas dunia. Hal tersebut tentunya berlaku bagi semua karyawan, termasuk karyawan yang sudah menikah. Peneliti memilih karyawan Wisma Bahasa Yogyakarta sebagai subjek penelitian dikarenakan dari hasil wawancara awal 3 dari 4 orang karyawan Wisma Bahasa Yogyakarta memiliki work engagement yang rendah. Padahal seharusnya Wisma Bahasa Yogyakarta sebagai pemimpin pasar di antara lembaga pelatihan bahasa di Yogyakarta memerlukan karyawan yang mencurahkan energinya secara positif sehingga menghasilkan kinerja yang terbaik, bekerja dengan antusias, dan berkonsentrasi penuh pada pekerjaannya untuk mampu mempertahankan prestasinya. Asumsi ini didukung oleh Bakker dan Leiter (2010) yang menyatakan bahwa di era sekarang ini perusahaan tidak hanya harus merekrut karyawan-karyawan terbaik, tetapi juga harus dapat mendorong para karyawan untuk memberikan performance terbaiknya. Oleh karena itu, organisasi modern mengharapkan para karyawannya untuk dapat bersikap proaktif dan penuh inisiatif, dan mengambil tanggung jawab sebagai bagian dari perkembangan profesional mereka dan komitmen terhadap standar kinerja yang tinggi (Bakker \& Leiter, 2010). Berlandaskan kebutuhan tersebut perusahaan membutuhkan karyawan-karyawan yang energik dan berdedikasi, yaitu karyawan yang memiliki keterikatan atau work engagement yang tinggi di dalam menjalani pekerjaannya.

Effendy dan Suharianto mengatakan bahwa kinerja dapat dicapai secara optimal bagi karyawan apabila mereka mempunyai work engagement yang memadai. Ketika individu merasa terlibat dengan pekerjaan, individu tersebut merasakan menyatu dengan tugas pekerjaannya dan tidak mudah terpengaruh dengan kondisi di sekelilingnya, dan perasaan ni tidak bisa 
didapatkan di tempat atau kegiatan lain. Sebaliknya, jika individu merasa tidak memiliki work engagement yang memadai maka individu tersebut merasa sangat tidak antusias dalam pekerjaan, tidak berkomitmen, yang membuat mereka tidak termotivasi dalam pekerjaannya. Karyawan dengan work engagement yang rendah juga merasa bahwa pekerjaannya sebagai tuntutan hidup sehingga mereka tidak merasakan keterikatan dengan pekerjaan, yang berdampak pada turunnya produktivitas.

Work engagement diartikan sebagai suatu pikiran yang positif terkait dengan pekerjaan dan pemenuhan diri. Pada karyawan yang sudah menikah, work engagement merefleksikan tingginya semanga dan dedikasi, serta absorbsi (Schaufeli, Salanova, Bakker, \& Alezrom, 2002). Kahn (1990) berpendapat bahwa karyawan dengan work engagement yang memadai adalah karyawan yang menghargai dirinya baik secara fisik, kognitif, maupun emosional saat bekerja. Sebaliknya, karyawan dengan work engagement yang rendah adalah karyawan yang menarik diri secara fisik, kognitif, dan emosional ketika bekerja. Schaufeli dkk. (2002) menyatakan bahwa work engagement memiliki 3 aspek. Aspek pertama adalah vigor yang merupakan curahan energi karyawan untuk melakukan pekerjaan yang terbaik dan adanya rasa senang atau kegembiraan terhadap setiap pekerjaannya. Vigor juga mencerminkan kerelaan karyawan untuk memberikan usaha yang maksimal terhadap kinerjanya dan ketahanan mental ketika menemui kesulitan dalam bekerja. Aspek mkedua adalah dedication, yaitu suatu kondisi dimana karyawan merasa terlibat sangat kuat dalam suatu pekerjaan dan mengalami rasa kebermaknaan, antusiasme, kebanggaan, inspirasi dan tantangan. Aspek ketiga adalah absorption, yaitu suatu kondisi dimana karyawan merasa waktu berjalan sangat cepat karena terlarut dalam pekerjaannya.

Menurut Robertson (dalam Aidina \& Prihatsanti, 2017), karyawan yang engaged akan membantu perusahaan untuk mengembalikan kestabilan perusahaan atau organisasi pada saat perusahaan dalam kondisi kesulitan. Selain itu, karyawan yang terikat akan bekerja secara aktif dalam sebuah organisasi dan mencoba berfikir untuk melakukan hal yang lebih baik. Hal ini dikarenakan karyawan yang memiliki keterikatan kerja yang kuat memiliki pemahaman yang baik tentang kemampuan yang mereka miliki dalam melakukan pekerjaan. Chalofsky dan Krisna (dalam Aidina \& Prihatsanti, 2017) menambahkan bahwa karyawan dengan work engagement yang rendah akan merasa tidak cocok antara kemampuan mereka yang miliki dengan tugastugas yang mereka emban. Selain itu, dalam bekerja mereka juga merasa kurang bersemangat dan menunjukan rasa tidak bahagia terhadap pekerjaan yang dilakukan.

Menurut Bates (dalam Yudiani, 2017), beberapa tahun belakangan ini minat untuk mengkaji work engagement tampak semakin besar. Hal itu menunjukan bahwa permasalahan work engagement sangat penting untuk diteliti. Beberapa peneliti pun menegaskan bahwa work engagement berperan dalam meningkatkan produktivitas karyawan, keberhasilan organisasi, dan kinerja finansial.

Terdapat beberapa faktor yang mempengaruhi work engagement. Bakker dan Bakker (2011) menyatakan bahwa work engagement dipengaruhi oleh 2 faktor. Faktor pertama adalah job resources, yang mengacu pada sumber daya pekerjaan baik aspek fisik, sosial, maupun organisasi. Job resources bisa mempengaruhi tuntutan pekerjaan, biaya fisiologis dan psikologis, fungsional dalam mencapai tujuan kerja, serta pertumbuhan, pembelajaran, dan pengembangan pribadi. Personal resources, atau sumber daya pribadi, adalah evaluasi diri positif yang terkait dengan ketahanan dan merujuk pada perasaan individu tentang kemampuan karyawan untuk berhasil mengendalikan lingkungan kerja. Aspek-aspek job resources yang dapat mempengaruhi work engagement pada karyawan adalah aspek sosial 
dari pekerjaan yang dapat merangsang pertumbuhan, pembelajaran, dan pengembangan pribadi. Lebih lanjut, karyawan yang memiliki pengalaman dalam pekerjaan dapat termotivasi untuk mengembangkan kemampuannya di lingkungan sosialnya seperti keluarga. Interaksi antara pekerjaan dan keluarga, yang menggambarkan sejauhmana pengalaman dan partisipasi di dalam sebuah peran mampu meningkatkan kinerja di peran yang lainnya merupakan pengertian dari workfamily enrichment (Greenhaus \& Powell, 2006).

Work-family enrichment memberikan manfaat positif bagi seseorang yang telah berkeluarga dimana sumber daya, pengaruh positif, dan modal psikososial seseorang tersebut bisa berkembang (Carlson, Kacmar, Wayne, \& Grzywacz, 2006). Lebih lanjut, Carlson dkk. (2006) menjelaskan bahwa workfamily enrichment memiliki 3 dimensi. Pertama adalah dimensi afek, yaitu keterlibatan dalam bekerja yang menghasilkan keadaan emosi positif dan sikap yang membantu individu menjadi anggota keluarga yang lebih baik. Kedua adalah dimensi pengembangan, yang menggambarkan keterlibatan dalam kerja yang bisa memperbaiki keterampilan, pengetahuan atau perilaku yang membantu individu menjadi anggota keluarga yang lebih baik. Ketiga adalah dimensi modal psikososial, yaitu keterlibatan dalam kerja yang meningkatkan sumber daya seperti rasa aman, prestasi atau pemenuhan diri, yang memudahkan individu untuk meraih kesuksesan.

Work-family enrichment berkaitan dengan keterikatan seseorang dengan pekerjaannya. Karyawan yang memiliki work-family enrichment yang tinggi akan memiliki keterikatan dengan pekerjaan yang tinggi. Hal tersebut didukung oleh penelitian yang dilakukan oleh Marais, Klerk, Nel, dan Beer (2015). Hasil penelitian tersebut menunjukan bahwa ketika pekerja perempuan mengalami peningkatan work-family enrichment, maka mereka lebih terikat dalam pekerjaan yang dilakukan. Hal ini mengandung arti bahwa ketika seorang pekerja perempuan memperoleh sumber daya seperti dukungan kerja, otonomi kerja serta kemampuan mentransfer sumber daya tersebut bisa dikembangkan dalam kehidupan keluarganya. Pengembangan ini selanjutnya membuat pekerja merasa engaged dengan pekerjaannya. Hal ini disebabkan karena sumber daya yang diperoleh pekerja perempuan mampu meningkatkan dan memperbaiki kualitas kehidupan keluarga pekerja. Dampak postifnya adalah pekerja perempuan merasa lebih terikat dalam pekerjaannya karena melihat bahwa pekerjaan yang dilakukan dapat dijadikan sebagai sumber yang memungkinkan pekerja untuk menjadi anggota keluarga yang lebih baik (Marais dkk., 2015). Karyawan yang memiliki work-family enrichment negatif akan memiliki konflik antara pekerjaan dan keluarga, dan mereka mengalami ketegangan dalam menghadapi berbagai tuntutan baik tuntutan dari ranah pekerjaan ataupun tuntutan dari ranah keluarga (Kesumaningsari \& Simarmata, 2014). Schaufeli, Bakker, dan Rhenen (2009) mengemukakan bahwa selama berkonflik individu akan diliputi proses ketegangan (strain process), yang sangat menguras energi mental yang kemudian menyebabkan keterikatan pekerja baik secara fisik maupun emosional terhadap pekerjaannya menjadi berkurang. Penelitian sebelumnya tentang work-family enrichment dan work engagement sangat terbatas pada subjek perempuan sehingga penelitian ini berusaha mengisi kekurangan dari penelitian sebelumnya dengan tidak menggolongkan karyawan berdasarkan jenis kelamin.

Berdasarkan uraian latar belakang di atas, peneliti ingin mengajukan rumusan masalah dalam penelitian ini, yaitu apakah ada hubungan antara work-family enrichment dengan work engagement pada karyawan Wisma Bahasa Yogyakarta yang sudah menikah? 


\section{Metode}

\section{Desain penelitian}

Desain yang digunakan dalam penelitian ini adalah survei korelasional cross-sectional (Johnson, 2001). Dengan desain ini, variabelvariabel penelitian, yaitu work-family enrichment dan work-engagement diukur dengan suatu skala dalam waktu yang bersamaan.

\section{Partisipan}

Subjek dalam penelitian ini adalah 39 karyawan Wisma Bahasa Yogyakarta yang sudah menikah. Pengambilan subjek dalam penelitian ini menggunakan teknik purposive sampling (Hibberts, Johnson, \& Hudson, 2012) dimana pemilihan subjek disesuaikan dengan kriteria yang telah peneliti tetapkan, yaitu karyawan yang sudah menikah.

\section{Instrumen penelitian}

Metode penyusunan skala dalam penelitian ini mengacu pada model likert (Croasmun \& Ostrom, 2011). Skala yang digunakan dalam penelitian ini, pertama, adalah skala work-family enrichment yang disusun oleh peneliti berdasarkan pada dimensi-dimensi work-family enrichment dari Carlson dkk., (2006). Kedua adalah skala work engagement yang disusun oleh peneliti berdasarkan aspekaspek work engangement dari Schaufeli dkk. (2002). Aitem-aitem dalam skala in hanya dibagi dalam satu kelompok, yaitu kelompok favourable. Skala work-family enrichment terdiri dari 15 aitem dengan koefisien aitemtotal $\left(r_{\mathrm{ix}}\right)$ bergerak dari rentang 0.384 sampai dengan 0.743. Sementara itu, skala work engagement terdiri dari 15 aitem dengan koefisien aitem-total $\left(r_{\mathrm{ix}}\right)$ bergerak dari rentang 0.304 sampai dengan 0.635. Dalam pengisian kuesioner, subjek diminta untuk mengisi kuesioner berbentuk paper-and-pencil dengan 4 alternatif pilihan jawaban yang tersedia, yaitu sangat sesuai (SS), sesuai (S), tidak sesuai (TS), dan sangat tidak sesuai (STS).

Berdasarkan hasil perhitungan, skala work-family enrichment memiliki koefisien reliabilitas alpha Cronbach $(\alpha)$ sebesar 0.897, sementara skala work engagement memiliki koefisien reliabilitas alpha Cronbach $(\alpha)$ sebesar 0.844. Metode analisis data menggunakan teknik korelasi product moment. Keseluruhan data dianalisis menggunakan program analisis data SPSS for Windows (Field, 2013).

\section{Hasil}

Uji normalitas menggunakan teknik analisis model Shapiro-Wilk (Doornik \& Hansen, 2008). Hasil analisis menunjukkan bahwa nilai Shapiro-Wilk work engagement adalah sebesar $0.955, p=0.124$, dan nilai Shapiro-Wilk work-family enrichment adalah sebesar 0.974, $p=0.489$. Data tersebut menunjukkan bahwa skor variabel work engagement dan skor variabel work-family enrichment berdistribusi normal. Sementara itu, hasil uji linearitas menghasilkan nilai $F=$ 29.757, $p<.001$, yang menunjukkan bahwa hubungan antara work-family enrichment dengan work engagement merupakan hubungan yang linier. Analisis Pearson's product moment correlation (Rupinski \& Dunlap, 1996) menghasilkan nilai korelasi yang signifikan, $r_{\mathrm{xy}}$ $=0.652, p<0.05$. Nilai korelasi ini mengandung arti bahwa work-family enrichment berhubungan secara signifikan ke arah postif dengan work engagement pada karyawan yang sudah menikah dan bekerja di Wisma Bahasa Yogyakarta. Implikasinya, semakin tinggi work-family enrichment maka semakin tinggi work engagement, dan sebaliknya, semakin rendah work-family enrichment maka semakin rendah work engagement. Hasil ini dengan demikian mendukung hipotesis dalam penelitian ini. Nilai korelasi antara work-family enrichment dengan work engagement sebesar 0.652 termasuk koefisien nilai korelasi yang kuat (Sugiyono, 2015).

\section{Diskusi}

Hasil penelitian menunjukkan adanya hubungan positif yang signifikan antara work- 
family enrichment dengan work engagement pada karyawan yang sudah menikah. Adanya korelasi tersebut membuktikan bahwa workfamily enrichment mempunyai peran penting terhadap work engagement pada karyawan Wisma Bahasa Yogyakarta yang sudah menikah. Hasil penelitian ini mendukung penelitian sebelumya yang dilakukan Kuntari (2017) yang menunjukkan bahwa terdapat hubungan positif antara work-family enrichment dengan work engagement. Adanya hubungan antara work-family enrichmnent dengan work engagement mengandung arti bahwa setiap aspek work family enrichment memberikan sumbangan terhadap work engagement pada karyawan Wisma Bahasa Yogyakarta yang sudah menikah.

Ketika mengalami peningkatan workfamily enrichement, pekerja merasa lebih terikat dalam pekerjaan yang dilakukan. Hal ini memberikan dampak positif dimana sumber daya berupa dukungan kerja yang pekerja dapatkan bisa mengembangkan kemampuan dan otonomi kerjanya, serta kemampuan mentransfer sumber daya yang sudah diperoleh tersebut ke dalam kehidupan keluarganya. Mekanisme ini selanjutnya membuat pekerja merasa engaged dengan pekerjaannya. Hal ini disebabkan karena sumber daya yang diperoleh pekerja dari pekerjaan yang dilakukan mampu meningkatkan dan memperbaiki kualitas kehidupan keluarga pekerja. Dalam hal ini, keterikatan pekerja dengan pekerjaannya menjadi lebih kuat karena pekerja tersebut melihat bahwa pekerjaan yang dilakukan dapat dijadikan sebagai sumber yang memungkinkannya untuk menjadi anggota keluarga yang lebih baik (Marais dkk., 2015). Menurut Carlson dkk (2006) work-family enrichment memiliki 3 dimensi yaitu afek, pengembangan, dan modal psikososial.

Karyawan yang memiliki afek positif akan memperoleh kesenangan dan suasana hati yang gembira ketika masuk dalam lingkungan organisasi. Perasaan positif inilah yang kemudian dibawa ketika pulang dan menjadikan individu menjadi anggota keluarga yang lebih baik meskipun individu seharian bekerja secara penuh (Carlson dkk., 2006). Ketika merasakan pengaruh positif seperti peningkatan kualitas hidup dalam menjalankan peran dalam pekerjaan atau keluarga, karyawan menjadi lebih bersemangat dalam melakukan pekerjaannya (Klerk, Nel, \& Koekemoer, 2015). Jika dilihat dari dimensi pengembangan, karyawan yang memiliki pengembangan positif memperoleh kemampuan yang lebih ketika bergabung menjadi anggota pada organisasi. Kemampuan ini berguna untuk meningkatkan peran individu yang lainnya (Carlson dkk., 2006). Sementara itu, adanya pengetahuan, keterampilan, dan sumber daya yang dimiliki dalam pekerjaan bisa meningkatkan perasaan positif yang terkait dengan peran di pekerjaan maupun peran di keluarga secara bersamaan (Greenhaus \& Powell, 2006). Karyawan yang mengaplikasikan pengetahuan dan memanfaatkan keterampilan serta sumber daya yang diperoleh dari pekerjaan ke kehidupan keluarga cenderung memiliki identitas yang kuat pada pekerjaannya, dan menganggap pekerjaannya sebagai sesuatu yang berarti, inspirasional, dan menantang (Bakker \& Demerouti dalam Kuntari, 2017).

Pada dimensi modal psikososial, karyawan yang memiliki modal psikososial yang positif akan merasakan bahwa pekerjaan yang dilakukan dapat membuat karyawan merasa aman, berprestasi, dan memiliki peluang untuk sukses dalam pekerjaannya. Lebih lanjut, hal tersebut didapatkan oleh karyawan melalui interaksi di dalam lingkungan organisasi sehingga mampu meningkatkan kepercayaan diri yang dapat membantu karyawan menjadi anggota keluarga yang lebih baik (Carlson dkk., 2006). Kuntari (2017) menyatakan bahwa keterlibatan secara fisik, emosional dan kognitif pada pekerjaan berpeluang untuk meningkatkan keberhasilan dalam menjalankan pekerjaan. Lebih lanjut dijelaskan bahwa keberhasilan dalam pekerjaan akan memunculkan kondisi afektif atau kondisi emosi yang positif pada 
karyawan sebagai hasil penilaian terhadap pekerjaannya. Dengan demikian, karyawan lebih bersemangat (vigor) saat menjalankan tugas dan tanggung jawabnya, yang mendorong mereka menjadi lebih berdedikasi pada tugas (dedication) dan merasa senang atau bahagia dengan profesinya meskipun harus bekerja keras (absorption).

Penelitian ini, bagaimanapun juga, memiliki sejumlah kekurangan. Terdapat sejumlah saran yang peneliti harapkan bisa menutupi kekurangan-kekurangan tersebut. Pertama, peneliti selanjutnya diharapkan menguji variabel lain selain work-family enrichment yang secara teoretis dan empiris bisa memprediksi atau mempengaruhi work engagement, baik variabel demografis seperti tingkat pendidikan dan variabel situasional seperti konflik keluarga (Burke, Koyuncu, Fiksenbaum, \& Tekin, 2013), serta faktor kepribadian (Akhtar, Boustani, Tsivrikos, \& Chamorro-Premuzic, 2015). Peneliti berikutnya juga bisa menggunakan sampel lain selain karyawan yang sudah menikah di Hotel Wisma Yogyakarta untuk menguji validitas eksternal (Steckler \& McLeroy, 2008) dari penelitian ini, yang mencerminkan sejauhmana hasil penelitian ini bisa digeneralisasikan pada responden dan konteks dengan karakteristik yang berbeda. Saran perbaikan berikutnya terkait dengan pentingnya bagi penelitian berikutnya untuk menguji dampak atau konsekuensi dari work engagement, sebagaimana telah dilakukan dalam penelitianpenelitian sebelumnya (Halbesleben, 2011; Menguc, Auh, Fisher, \& Haddad, 2013).

Memperhatikan peran signifikan workfamily enrichment dalam menjelaskan work engagement, saran praktis dalam penelitian difokuskan pada pentingnya bagi pekerja yang sudah menikah untuk meningkatkan workfamily enrichment. Mengacu pada hasil-hasil penelitian sebelumnya, peningkatan workfamily enrichment bisa dilakukan dengan mempertimbangkan sejumlah faktor, seperti dukungan keluarga, dukungan rekan kerja, kebijakan work-life balance, serta work-family culture (Baral \& Bhargava, 2011a, 2011b).

\section{Daftar Pustaka}

Aidina, N. R., \& Prihatsanti, U. (2017). Hubungan antara kepercayaan terhadap pemimpin dengan keterikatan kerja pada karyawan pt telkom witel semarang. Jurnal Empati, 6(4), 137-142. Diakses dari https://ejournal3.undip.ac.id/index.php/e mpati/article/viewFile/20002/18886

Akhtar, R., Boustani, L., Tsivrikos, D., \& Chamorro-Premuzic, T. (2015). The engageable personality: Personality and trait EI as predictors of work engagement. Personality and Individual Differences, 73, 44-49. https://doi.org/10.1016/j.paid.2014.08.040 Amelia, A. (2010). Pengaruh work-to-family conflict dan family-to-work conflict terhadap kepuasan dalam bekerja, keinginan pindah tempat kerja, dan kinerja karyawan. Jurnal Ekonomi dan Bisnis, 4(3), 201-220.

Bakker, A. B., \& Bakker, A. B. (2011). An evidence-based model of work engagement. Current Directions in Psychological Science, 20(4), 265-269. https://doi.org/10.1177/096372141141453 4

Bakker, A. B., \& Leiter, M. P. (Eds.). (2010). Work engagement : A handbook of essential theory and research. New York, USA: Psychology Press. Diakses dari https://tandfbis.s3.amazonaws.com/rtmedia/pp/common/samplechapters/9781841697369.pdf

Baral, R., \& Bhargava, S. (2011a). Examining the moderating influence of gender on the relationships between work-family antecedents and work-family enrichment. Gender in Management: An International Journal, 26(2), 122-147. https://doi.org/10.1108/175424111111165 45 
Baral, R., \& Bhargava, S. (2011b). Predictors of work-family enrichment: Moderating effect of core self-evaluations. Journal of Indian Business Research, 3(4), 220-243. https://doi.org/10.1108/175541911111805 73

Burke, R. J., Koyuncu, M., Fiksenbaum, L., \& Tekin, Y. (2013). Antecedents and consequences of work engagement among frontline employees in Turkish hotels. Journal of Transnational Management, 18(3), 191-203. https://doi.org/10.1080/15475778.2013.81 7243

Caldwell, C., Truong, D. X., Linh, P. T., \& Tuan, A. (2011). Strategic human resource management as ethical stewardship. Journal of Business Ethics, 98(1), 171-182. https://doi.org/10.1007/s10551-0100541-y

Carlson, D. S., Kacmar, K. M., Wayne, J. H., \& Grzywacz, J. G. (2006). Measuring the positive side of the work-family interface: Development and validation of a workfamily enrichment scale. Journal of Vocational Behavior, 68(1), 131-164. https://doi.org/10.1016/j.jvb.2005.02.002

Croasmun, J. T., \& Ostrom, L. (2011). Using Likert-Type Scales in the Social Sciences. Journal of Adult Education, 40(1), 19-22. Diakses dari https://files.eric.ed.gov/fulltext/EJ961998. pdf

Doornik, J. A., \& Hansen, H. (2008). An omnibus test for univariate and multivariate normality. Oxford Bulletin of Economics and Statistics, 70, 927-939. https://doi.org/10.1111/j.14680084.2008.00537.x

Effendy., N., \& Suharianto. (2015). Pengaruh psychological capital terhadap work engagement pada dosen di universitas katolik widya mandala surabaya. Jurnal Experienta, 3(2), 23-34. https://doi.org/10.33508/exp.v3i2.905
Field. A. (2013). Discovering statistics using SPSS ( $4^{\text {th }}$ edition). London, UK: Sage Publication Ltd.

Greenhaus, J. H., \& Powell, G. N. (2006). When work and family are allies: A theory of work-family enrichment. The Academy of Management Review, 31(1), 72-92. https://doi.org/10.5465/amr.2006.193796 25

Halbesleben, J. R. (2011). The consequences of engagement: The good, the bad, and the ugly. European Journal of Work and Organizational Psychology, 20(1), 68-73. https://doi.org/10.1080/1359432X.2010.5 14327

Hibberts M., Johnson R. B., \& Hudson K. (2012). Common survey sampling techniques. In: Gideon L. (ed.), Handbook of survey methodology for the social sciences. New York, USA: Springer. https://doi.org/10.1007/978-14614-3876-2_5

Johnson, B. (2001). Toward a new classification of nonexperimental quantitative research. Educational Researcher, 30(2), 3-13.

https://doi.org/10.3102\%2F0013189X030 002003

Kahn, W. A. (1990). Psychological conditions of personal engagement and disengagement at work. Academy of Management Journal, 33(4), 692-725. https://doi.org/10.5465/256287

Kesumaningsari, N, A, dan Simarmata, N. dan. (2014). Konflik kerja-keluarga dan work engagement karyawati Bali pada bank di Bali. Psikologi Udayana, 1(3), 493-506. Diakses dari https://ojs.unud.ac.id/index.php/psikologi/ article/view/25131/16344

Klerk, M. De, Nel, J. A., \& Koekemoer, E. (2015). Work-to-family enrichment: Influences of work resources, work engagement and satisfaction among employees within the South African context. Journal of Psychology in Africa, 
25(6), 537-546.

https://doi.org/10.1080/14330237.2015.11 24606

Kuntari, C. M. I. S. R. (2017). Hubungan workfamily enrichment dengan work engagement pada perawat wanita. Jurnal Psikologi Ulayat, 2(1), 407. https://doi.org/10.24854/jpu12015-35

Marais, E., De Klerk, M., Nel, J. A., \& De Beer, L. (2015). The antecedents and outcomes of work-family enrichment amongst female workers. SA Journal of Industrial Psychology, 40(1), 1-14. https://doi.org/10.4102/sajip.v40i1.1186

Menguc, B., Auh, S., Fisher, M., \& Haddad, A. (2013). To be engaged or not to be engaged: The antecedents and consequences of service employee engagement. Journal of Business Research, 66(11), 2163-2170. https://doi.org/10.1016/j.jbusres.2012.01. 007

Rupinski, M. T., \& Dunlap, W. P. (1996). Approximating Pearson product-moment correlations from Kendall's tau and Spearman's rho. Educational and Psychological Measurement, 56(3), 419429.

https://doi.org/10.1177\%2F00131644960 56003004

Samsuni. (2017). Manajemen sumber daya manusia. Al-Falah, 17(31), 113-124. Diakses dari http://ejurnal.staialfalahbjb.ac.id/index.ph p/alfalahjikk/article/download/19/88

Schaufeli, W. B., Bakker, A. B., \& Rhenen, W. V. A. N. (2009). How changes in job demands and resources predict burnout, work engagement, and sickness absenteeism. 30(7), 893-917. https://doi.org/10.1002/job

Schaufeli, W. B., Salanova, M., Bakker, A. B., \& Alez-rom, V. G. (2002). The measurement of engagement and burnout: A two sample confirmatory factor. Journal of Happines Studies, 3, 71-92.
https://doi.org/10.1023/A:10156309303 26

Steckler, A., \& McLeroy, K. R. (2008). The importance of external validity. American Journal of Public Health, 98(1), 9-10.

Diakses dari

https://ajph.aphapublications.org/doi/pdf/ 10.2105/AJPH.2007.126847

Sugiyono. (2015). Metode penelitian dan pengembangan. Bandung: CV. Alfabeta.

Wulandari, S., Nurtjahjanti, H., \& Putra, N. A. (2013). Hubungan antara persepsi terhadap gaya kepemimpinan transformasional dengan work engagement pada karyawan pt. dua kelini Pati. Jurnal Empati, 2(3), 526-535.

Diakses dari https://ejournal3.undip.ac.id/index.php/e mpati/article/download/7376/7136

Yudiani, E. (2017). Work engagement karyawan PT. Bukit Asam, PERSERO ditinjau dari spiritualitas. Psikis: Jurnal Psikologi Islami, 3(1), 21-32. https://doi.org/10.19109/psikis.v3i1.1390 